\title{
Comparison between Science and Technology and Social Science Students' Understanding towards General Studies
}

\author{
Nazri Muslim ${ }^{1} \&$ Zaharah Hassan ${ }^{1}$ \\ ${ }^{1}$ Center for University Citra, National University of Malaysia, Malaysia \\ Correspondence: Nazri Muslim, Center for University Citra, national University of Malaysia, 43600 Bangi, \\ Selangor, Malaysia. E-mail: nazrimuslim@yahoo.com
}

Received: June 30, 2014 Accepted: September 8, 2014 Online Published: October 30, 2014

doi:10.5539/ass.v10n22p80

URL: http://dx.doi.org/10.5539/ass.v10n22p80

\begin{abstract}
Amid the fact that general studies have been regarded as a holistic education and that they are capable in producing all-rounders, in Malaysia specifically we have only met with the paucity of research that has automatically impeded any validation of the fact. In UKM for instance, the concept of general studies begins simultaneously with the establishment, but just how far it is effective is open to debate. In generality, it can be said that both students and the faculty have underestimated the significance of general study courses. The emphasis on the broadening of this general studies in principle is consistent with the aspirations of liberal education at the initial phase of the establishment of the UKM, which is towards creating graduates who can think laterally and in balance. This study seeks to analyse the views of UKM students on how they understand the philosophy and importance of general studies. This study involves 400 respondents who were chosen among third year students who have registered for the courses. The study data were obtained through a questionnaire using the SPSS program. Descriptive statistics such as frequency, percentage, mean, cross-tabulation statistics, and correlation coefficient were employed to explain respondents backgrounds and assess students' views on generic skill courses. The study outcome demonstrates that students have regarded highly over the generic skill courses, in general. There has been an insignificant difference between social science and science and technology students. Based on the study findings, several suggestions have been put forth for the improvement of generic skill courses so that it will produce students who have generic skills needed for the workplace market.
\end{abstract}

Keywords: general studies, university students, perception, higher education, national university of Malaysia

\section{Introduction}

In the era of global competition, universities not only need to produce graduates who have the technical efficacy but also attention must be given to the component of general studies, in order to develop students in a holistic manner. General studies involve the inculcation of skills, the expansion or broadening of knowledge, and a certain attitude that can help graduates undertake life effectively at the individual, organisational and global levels. Unfortunately, in most developing countries including Malaysia, the call for human labour to cater for the needs of the industry that is growing rapidly, has given an impact to the development of general studies. Thus, we should not be surprised as to why higher institutions today concentrate more on "specification" to produce graduates that have been regarded as "job-ready" so much so that there are a lot of students, as well as parents, have the view that general studies are unimportant and burdensome.

Among the academicians themselves, there are many of them who see general studies as having low status. The faculty does not stress on the general study component and allow the students to choose their course in a "fragmented" form, without giving any depth and meaning to their course planning.

Due to these attitude and practice, the work market is filled with university graduates that are not able to meet their employers' expectations and requirements. In a study done by Lazerson, Wagener \& Shumanis (2000) it shows that only $1 / 3$ from 1400 higher learning institutions in the USA asses their students in terms of their "higher-order learning skills, affective development or profesional development". This sits well with Oblinger \& Verville (1998) who write that there are many employers who report that these adult graduates are weak at several skills such as writing, verbal communication, teamwork and lifelong learning. This statement is supported by the Association of American Colleges and Universities (2008) who states that employers tend to look for apprentices who have high capability and skills in areas namely problem-solving, teamwork, 
communication and leadership.

In Malaysia too, the public opines that the failure of the graduates to get a job is explained by the fact that they do not have the soft skills or human skills that are very much needed by employers. It has been found by Haslinda, Muhammad Nubli dan Zarina (2005) that the marketability of every graduates is measured through various aspects and the employers are inclined to look for future apprentices that who possess various skills without having to give them in-service training.

The study done by the Center of Academic Development (CADE) UPM finds that issues related to human skills stay at the tenth rank during the interview, as compared to academic-related issues staying at the 18th rank (Shatar \& Mohamad, 2008). This shows that matters related to the formation of students' human skills must be given serious attention especially at the level of Higher Learning Institute in Malaysia.

\section{The Concept of General Studies}

Liberal education is education that promotes the limitless spirit of inquiry without the restriction of title that is labeled as relevant or fundamental to the vocational requirements. General studies serve as one component under this liberal education. It is also a form of education that allows people to undergo a more meaningful life. The subject learned, skills mastered and the mind habit inculcated and obtained in the process undertaken by a student will shape their life in the future, or when they complete their university years (Report of the Task Force on General Education Harvard University, 2007).

The education at the university level carries many dimensions as proven in associations, involvement in arts and culture, sports and lives in college. All these contribute to intellectual development, the inculcation of ethics and student's self-development. Academic experiences are also the central core of all these experiences. Normally, studies at the university level contain three main components and they are specification, elective and general studies.

Specification enables students to learn in depth about the discipline of knowledge of their choice. Elective subjects enable them to explore the field outside their subjects that have become their focus other than expanding their knowledge. Meanwhile, for subjects under general studies, they have the role to connect those learned in the university with the outside world. General studies also make students better understand and appreciate the complex world and their role in that world.

In the General Study Center, Universiti Kebangsaan Malaysia, General Studies is defined as a pre-graduate education that seeks to provide the students with preparatory knowledge to survive in modern society. The knowledge encompasses the understanding on noble values, history and responsibility in the society; skills on the quantitative analysis and communication techniques; delving into the elements of arts and culture, and the ability to use pastime productively.

In UKM, between 15 and 20 percent credits that must be taken by students throughout their courses comprise of courses that can be categorized as general study courses. The courses are offered by the faculty and also the General Study Center (PPU) and other centers. Courses in the PPU are divided into U1 courses which are compulsory courses, courses U2 that stress on skill acquisition, courses U3 which open doors for the expansion of knowledge and courses U4 that stress on the mastery of English and the Malay Language.

At the university level, although the importance of general studies is reflected through the total number of credits allocated, but in practice, the majority of people in the campus see general study courses as one that needs to be taken only to fulfill the requirement. The faculty often encourages the students to "complete" general study courses as soon as they can to concentrate on core courses. There are even some quarters who suggest that the number of credits allocated should be reduced. Why does this continue to happen when students' incapacity in areas contained in general studies is widely reported?

\section{Study Objectives}

1) Identify the perceptions of students from science and technology and social science streams on the philosophy and importance of general studies.

2) Identify the perceptions of students from science and technology and social science streams on the fulfilling human skills.

3) Identify the perceptions of students from science and technology and social science streams on the mastery in the human skills. 


\section{Research Methodology}

This study employs a quantitative approach. The sample of study comprises of 400 students that were chosen at random. The instrument used is divided into Sections A, B, C and D covering aspects of demographic information, philosophical understanding, aims, importance and the enhanced human skills. To measure students' level of understanding, The Likert scale takes the form of 1 representing Strongly disagree, 2 Disagree, 3 Slightly disagree and 4 Agree and 5 Strongly Agree.

Data obtained have been analysed using the SPSS program version 16 through the descriptive statistics such as frequency, percentage and mean and they are used to explain about the demography of the respondents and the level of understanding of the students on general studies.

The "Cronbach Alpha" test was used to measure the reliability and consistency of the instrument. According to Nunally (1978) the "Cronbach Alpha" value must be more than 0.70 to indicate high reliability and consistency. Table 1 is an analysis showing reliability for the Section that uses the scale, such as Section B, Section C, and Section D. The value obtained shows that the item in the construct can be seen as reliable.

Table 1. "Cronbach Alpha" scores results

\begin{tabular}{lll}
\hline Section & Item & "Cronbach Alpha" Score \\
\hline Section B & 12 & 0.755 \\
Section C & 77 & 0.958 \\
Section D & 38 & 0.977 \\
Overall & 127 & 0.971 \\
\hline
\end{tabular}

To discuss the study findings descriptively in relation to their understanding, the mean score interpretation or classification level has been employed. The classification level is as shown in Table 2.

Table 2. Level of classification of students' understanding on general education

\begin{tabular}{ll}
\hline Classification Level & Range Level \\
\hline Low & $1.00-2.33$ \\
Moderate & $2.34-3.67$ \\
High & $3.68-5.00$ \\
\hline
\end{tabular}

Table 3. Distribution of respondents by gender, race, faculty and year of study

\begin{tabular}{ll}
\hline Demographic Characteristics & Percentage \\
\hline Gender & \\
- Male & 37.5 \\
- Female & 62.5 \\
Race & \\
- Malay & 81.5 \\
- Chinese & 16.3 \\
- Others & 2.8 \\
Year of Study & \\
- Year 2 & 43.5 \\
- Year 3 & 34.5 \\
- Year 4 & 22.0 \\
Faculty & \\
- FSSK & 8.5 \\
- FKAB & 27.8 \\
- FPI & 10.8 \\
- FST & 22.8 \\
- FEP & 17.5 \\
\hline
\end{tabular}


In this study, the division between science and technology students, also social science students is according to the faculty. For the science and technology students, the faculties involved are Science and Technology Faculty (FST) and Engineering and Built Environment Faculty (FKAB), whereas for social science students, the faculties involved are Social Science and Humanity Faculty (FSSK), Islamic Studies Faculty (FPI) and Economy and Management Faculty (FEP).

\section{Study Findings and Discussion}

\subsection{Demography}

The study respondents comprise of second, third and fourth year students. From 400 respondents, 250 are female students and 150 more are male students. The majority, or 324 students or by percentage $81.5 \%$ are Malay respondents. The second year students make up the largest group, or $43.5 \%$, followed by third-year students around 138 or $34.5 \%$ and year 4 students 88 or $22 \%$. The total number of respondents by faculty highlights that the students from the Engineering and Built Environment make up the largest group or 20\% or 111 students, then followed by students from Economy and Management Faculty 70 students or 17.5\%. Data on the demography of the respondents are summarized in Table 3.

5.2 Students' Perception on the Importance of General Studies According to Faculty of Science and Technology and Faculty of Social Science

Table 4. The importance of general studies regarded by students from the faculty of science and technology and faculty of social science

\begin{tabular}{|c|c|c|c|c|c|}
\hline No & Statement & Faculty \% & Disagree \% & Slightly disagree \% & Agree \% \\
\hline \multirow{5}{*}{1} & \multirow{5}{*}{$\begin{array}{l}\text { creating graduates who can use and adapt } \\
\text { the knowledge in various situations, levels } \\
\text { and cultures }\end{array}$} & FSSK & 2.9 & 2.9 & 94.1 \\
\hline & & FKAB & 12.3 & 17.3 & 70.4 \\
\hline & & FPI & & & 100.0 \\
\hline & & FST & & 3.3 & 96.7 \\
\hline & & FEP & & 8.6 & 91.4 \\
\hline \multirow{6}{*}{2} & \multirow{5}{*}{$\begin{array}{l}\text { creating graduates skilled enough to use } \\
\text { English as their work language }\end{array}$} & FSSK & 2.9 & 14.7 & 82.4 \\
\hline & & FKAB & 13.6 & 18.5 & 67.9 \\
\hline & & FPI & 2.3 & 2.3 & 95.3 \\
\hline & & FST & 4.4 & 9.9 & 85.7 \\
\hline & & FEP & 5.7 & 15.7 & 78.6 \\
\hline & \multirow{5}{*}{ creating graduates with good leadership } & FSSK & 2.9 & 2.9 & 94.1 \\
\hline \multirow{4}{*}{3} & & FKAB & 9.9 & 21.0 & 69.1 \\
\hline & & FPI & 2.3 & 2.3 & 95.3 \\
\hline & & FST & & 7.7 & 92.3 \\
\hline & & FEP & 1.4 & 12.9 & 85.7 \\
\hline \multirow{6}{*}{4} & \multirow{5}{*}{$\begin{array}{l}\text { creating graduates who can communicate } \\
\text { and interact in a team }\end{array}$} & FSSK & 2.9 & 2.9 & 94.1 \\
\hline & & FKAB & 7.4 & 19.8 & 72.8 \\
\hline & & FPI & 2.3 & & 97.7 \\
\hline & & FST & & 3.3 & 96.7 \\
\hline & & FEP & 1.4 & 4.3 & 94.3 \\
\hline & \multirow{5}{*}{$\begin{array}{l}\text { creating graduates who have the leadership } \\
\text { and direction in the context of function and } \\
\text { role of the society }\end{array}$} & FSSK & 2.9 & 2.9 & 94.1 \\
\hline \multirow{4}{*}{5} & & FKAB & 9.9 & 16.0 & 74.1 \\
\hline & & FPI & & 4.7 & 95.3 \\
\hline & & FST & 1.1 & 1.1 & 97.8 \\
\hline & & FEP & 1.4 & 7.1 & 91.4 \\
\hline \multirow{5}{*}{6} & \multirow{5}{*}{$\begin{array}{l}\text { creating graduates functioning } \\
\text { technocrats and bureaucrats }\end{array}$} & FSSK & 2.9 & 5.9 & 91.2 \\
\hline & & FKAB & 9.9 & 29.6 & 60.5 \\
\hline & & FPI & & 9.3 & 90.7 \\
\hline & & FST & 1.1 & 15.4 & 83.5 \\
\hline & & FEP & 1.4 & 24.3 & 74.3 \\
\hline
\end{tabular}


Table 5. The aim of general studies regarded by students from the faculty of science and technology and faculty of social science

\begin{tabular}{|c|c|c|c|c|c|}
\hline No. & Statement & Fac. & Disagree $\%$ & Slightly disagree \% & Agree $\%$ \\
\hline \multirow{5}{*}{1} & \multirow{5}{*}{$\begin{array}{l}\text { Prepare students to get involved and take part in } \\
\text { social activities/ community services }\end{array}$} & FSSK & 2.9 & 11.8 & 85.3 \\
\hline & & FKAB & 14.8 & 11.1 & 74.1 \\
\hline & & FPI & 2.3 & 9.3 & 88.4 \\
\hline & & FST & & 11.0 & 89.0 \\
\hline & & FEP & 1.4 & 15.7 & 82.9 \\
\hline \multirow{5}{*}{2} & \multirow{5}{*}{$\begin{array}{l}\text { Understand factors that influence changes at the } \\
\text { national and global levels }\end{array}$} & FSSK & & 5.9 & 94.1 \\
\hline & & FKAB & 6.2 & 27.2 & 66.7 \\
\hline & & FPI & 2.3 & 7.0 & 90.7 \\
\hline & & FST & & 13.2 & 86.8 \\
\hline & & FEP & & 17.1 & 82.9 \\
\hline \multirow{5}{*}{3} & \multirow{5}{*}{$\begin{array}{l}\text { Understand the diversity of cultures that shapes the } \\
\text { society and individual }\end{array}$} & FSSK & 5.9 & 2.9 & 91.2 \\
\hline & & FKAB & 7.4 & 23.5 & 69.1 \\
\hline & & FPI & & 7.0 & 93.0 \\
\hline & & FST & & 6.6 & 93.4 \\
\hline & & FEP & & 11.4 & 88.6 \\
\hline \multirow{5}{*}{4} & \multirow{5}{*}{$\begin{array}{l}\text { To expose students to advancement in the world of } \\
\text { science and technology }\end{array}$} & FSSK & 5.9 & 5.9 & 82.4 \\
\hline & & FKAB & 11.1 & 29.6 & 59.3 \\
\hline & & FPI & & 11.6 & 88.4 \\
\hline & & FST & 2.2 & 13.2 & 84.6 \\
\hline & & FEP & 1.4 & 27.1 & 71.4 \\
\hline \multirow{5}{*}{5} & \multirow{5}{*}{$\begin{array}{l}\text { To enable students to understand the role of arts, } \\
\text { ideas and values in shaping their identity }\end{array}$} & FSSK & 8.8 & 11.8 & 79.4 \\
\hline & & FKAB & 7.4 & 27.2 & 65.4 \\
\hline & & FPI & & 4.7 & 95.3 \\
\hline & & FST & & 13.2 & 86.8 \\
\hline & & FEP & 1.4 & 11.4 & 87.1 \\
\hline \multirow{5}{*}{6} & \multirow{5}{*}{$\begin{array}{l}\text { To prepare students to be capable of reacting to } \\
\text { changes critically and constructively }\end{array}$} & FSSK & & 11.8 & 88.2 \\
\hline & & FKAB & 12.3 & 24.7 & 63.0 \\
\hline & & FPI & & 7.0 & 93.0 \\
\hline & & FST & 1.1 & 7.7 & 91.2 \\
\hline & & FEP & 1.4 & 5.7 & 92.9 \\
\hline \multirow{5}{*}{7} & \multirow{5}{*}{$\begin{array}{l}\text { To build students' understanding on ethics-related } \\
\text { aspects in regard of their behaviour }\end{array}$} & FSSK & 2.9 & 14.7 & 82.4 \\
\hline & & FKAB & & 9.9 & 80.1 \\
\hline & & FPI & & 4.7 & 95.3 \\
\hline & & FST & 1.1 & 6.6 & 92.3 \\
\hline & & FEP & & 11.4 & 88.6 \\
\hline \multirow{5}{*}{8} & \multirow{5}{*}{$\begin{array}{l}\text { To produce graduates who have the morality, ethics, } \\
\text { creativity, tolerance and sanity from the } \\
\text { multi-disciplinary and cross-cultured perspectives in } \\
\text { contemporary issues }\end{array}$} & FSSK & 5.9 & 2.9 & 91.2 \\
\hline & & FKAB & 11.1 & 18.5 & 70.4 \\
\hline & & FPI & & 4.7 & 95.3 \\
\hline & & FST & 2.2 & 4.4 & 93.4 \\
\hline & & FEP & & 4.3 & 95.7 \\
\hline \multirow{5}{*}{9} & \multirow{5}{*}{$\begin{array}{l}\text { To equip students with generic skills needed in order } \\
\text { to function effectively as to cater for the needs of the } \\
\text { employers }\end{array}$} & FSSK & & 5.9 & 94.1 \\
\hline & & FKAB & 12.3 & 34.6 & 53.1 \\
\hline & & FPI & & 7.0 & 93.0 \\
\hline & & FST & 1.1 & 11.0 & 87.9 \\
\hline & & FEP & & 8.6 & 91.4 \\
\hline & & FSSK & & 5.9 & 94.1 \\
\hline & To produce graduates who think holistically by & FKAB & 9.9 & 27.2 & 63.0 \\
\hline 10 & integrating and balancing general and specific & FPI & & 2.3 & 97.7 \\
\hline & knowledge & FST & 1.1 & 7.7 & 91.2 \\
\hline & & FEP & & 12.9 & 87.1 \\
\hline & To produce graduates who master both the Malay & FSSK & 5.9 & 2.9 & 91.2 \\
\hline & Language and English for effective communication & FKAB & 17.3 & 24.7 & 58.0 \\
\hline 11 & verbally and in writing, at the individual, group and & FPI & & 4.7 & 95.3 \\
\hline & community levels in both academic and vocational & FST & & 8.8 & 91.2 \\
\hline & surroundings & FEP & & 5.7 & 94.3 \\
\hline
\end{tabular}


Based on the Table above, there is no significant difference between science-streamed students and social science students when viewing the importance of general studies to them. They share the opinion that general studies are important in developing self-potential such as the ability to communicate, have a sense of leadership and play a role in the community.

5.3 Students' Perception on the Aim of General Studies According to the Faculty of Science and Technology and Faculty of Social Science

The table above shows that, all in all, students from both science and social science streams agree that the aim held by general studies is able to produce holistic students-those fulfilling the work market. The aim of general studies is for students to be able to develop their own ethics, play a great role in the community and not solely mastering the disciplines of the core knowledge. Meanwhile, this aim is at par with the aim of education in UKM which is to create graduates who have the confidence, leadership and self-identity both nationally and internationally. Measurable characteristics in Educational goals are as established below:

1) Measurable Characteristics Domain "Confident"

- Possess strong knowledge in the field of study,

- Skilled in their respective field of knowledge,

- Can use and adapt the knowledge to various situations/circumstances, level and culture (innovative and creative),

- Skilled in using international/global work language (English).

2) Measurable Characteristics Domain "Leadership"

- Can communicate and interact in a team,

- Have a leadership and direction in the context of function and role of the community,

- Can make decisions and make smart actions based on ethics and universal values (fair, just, sustainable and have an integrity)

3) Measurable Characteristics Domain "National Identity"

- Highly ethical and morale.

- Have the skills and are comfortable in interacting among different cultures and religions,

- Proud and eloquent in using the mother tongue,

- Have the awareness to defend the country's sovereignty.

5.4 Students' Perception on General Studies According to Students of Faculty of Science and Technology and Faculty of Social Science in Fulfilling Human Skills Requirements

Table 6. General studies according to the faculty of science and technology and faculty of social science in fulfilling human skills requirements

\begin{tabular}{|c|c|c|c|c|c|}
\hline Bil. & Statement & Fac. & Disagree \% & Slightly disagree $\%$ & Agree $\%$ \\
\hline \multirow{5}{*}{1} & \multirow{5}{*}{$\begin{array}{l}\text { creating graduates that can make the } \\
\text { decisions and make smart moves based on } \\
\text { ethics and universal values }\end{array}$} & FSSK & 5.9 & 8.8 & 85.3 \\
\hline & & FKAB & 11.1 & 24.7 & 64.2 \\
\hline & & FPI & - & 9.3 & 90.7 \\
\hline & & FST & 1.1 & 4.4 & 94.5 \\
\hline & & FEP & - & 4.3 & 95.7 \\
\hline \multirow{5}{*}{2} & \multirow{5}{*}{ creating graduates with national identity } & FSSK & 5.9 & 8.8 & 85.3 \\
\hline & & FKAB & 8.6 & 28.4 & 63 \\
\hline & & FPI & 2.3 & 14 & 83.7 \\
\hline & & FST & 2.2 & 8.8 & 89 \\
\hline & & FEP & 1.4 & 10 & 88.6 \\
\hline \multirow{5}{*}{3} & \multirow{5}{*}{$\begin{array}{l}\text { creating graduates with high levels of } \\
\text { ethics and moral }\end{array}$} & FSSK & 5.9 & 5.9 & 88.2 \\
\hline & & FKAB & 7.4 & 21 & 71.6 \\
\hline & & FPI & - & 9.3 & 90.7 \\
\hline & & FST & 2.2 & 4.4 & 93.4 \\
\hline & & FEP & - & 7.1 & 92.9 \\
\hline
\end{tabular}




\begin{tabular}{|c|c|c|c|c|c|}
\hline Bil. & Statement & Fac. & Disagree $\%$ & Slightly disagree $\%$ & Agree $\%$ \\
\hline \multirow{6}{*}{4} & \multirow{5}{*}{$\begin{array}{l}\text { creating graduates who are skillful and } \\
\text { comfortable in their interactions among } \\
\text { cultures and religions }\end{array}$} & FSSK & - & 2.9 & 97.1 \\
\hline & & FKAB & 8.6 & 14.8 & 76.5 \\
\hline & & FPI & 2.3 & 2.3 & 95.3 \\
\hline & & FST & 1.1 & 6.6 & 92.3 \\
\hline & & FEP & 1.4 & 2.9 & 95.7 \\
\hline & \multirow{5}{*}{$\begin{array}{l}\text { creating graduates who are proud and } \\
\text { eloquent in using the mother tongue }\end{array}$} & FSSK & 2.9 & 26.5 & 70.6 \\
\hline \multirow{4}{*}{5} & & FKAB & 12.3 & 32.1 & 55.6 \\
\hline & & FPI & 7 & 23.3 & 69.8 \\
\hline & & FST & 3.3 & 13.2 & 83.5 \\
\hline & & FEP & 5.7 & 20 & 74.3 \\
\hline \multirow{6}{*}{6} & \multirow{5}{*}{$\begin{array}{l}\text { creating graduates with an awareness to } \\
\text { defend their country's sovereignty }\end{array}$} & FSSK & 5.9 & 5.9 & 88.2 \\
\hline & & FKAB & 13.6 & 25.9 & 60.5 \\
\hline & & FPI & 4.7 & 11.6 & 83.7 \\
\hline & & FST & 1.1 & 12.1 & 86.8 \\
\hline & & FEP & 1.4 & 14.3 & 84.3 \\
\hline & \multirow{5}{*}{$\begin{array}{l}\text { creating graduates who have the } \\
\text { confidence, leadership, ethics, and } \\
\text { national identity in the international } \\
\text { domain }\end{array}$} & FSSK & 5.9 & 5.9 & 88.2 \\
\hline \multirow{5}{*}{7} & & FKAB & 8.6 & 27.2 & 64.2 \\
\hline & & FPI & 2.3 & 2.3 & 95.3 \\
\hline & & FST & 1.1 & 4.4 & 94.5 \\
\hline & & FEP & & 8.6 & 91.4 \\
\hline & \multirow{5}{*}{$\begin{array}{l}\text { creating graduates with various skills } \\
\text { other than possessing strong knowledge } \\
\text { in their respective fields }\end{array}$} & FSSK & & 2.9 & 97.1 \\
\hline \multirow{5}{*}{8} & & FKAB & 11.1 & 21 & 67.9 \\
\hline & & FPI & & 9.3 & 90.7 \\
\hline & & FST & 3.3 & 6.6 & 90.1 \\
\hline & & FEP & & 7.1 & 92.9 \\
\hline & \multirow{5}{*}{$\begin{array}{l}\text { creating graduates who have the skills in } \\
\text { their respective fields }\end{array}$} & FSSK & 2.9 & 11.8 & 85.3 \\
\hline \multirow{4}{*}{9} & & FKAB & 17.3 & 22.2 & 60.5 \\
\hline & & FPI & & 14 & 86 \\
\hline & & FST & 1.1 & 16.5 & 82.4 \\
\hline & & FEP & 2.9 & 12.9 & 84.3 \\
\hline \multirow{5}{*}{10} & \multirow{5}{*}{$\begin{array}{l}\text { creating graduates who can use and adapt } \\
\text { the knowledge in various situations, } \\
\text { levels and cultures }\end{array}$} & FSSK & 8.8 & 2.9 & 88.2 \\
\hline & & FKAB & 11.1 & 25.9 & 63 \\
\hline & & FPI & & 11.6 & 88.4 \\
\hline & & FST & & 6.6 & 93.4 \\
\hline & & FEP & & 5.7 & 94.3 \\
\hline \multirow{5}{*}{11} & \multirow{5}{*}{$\begin{array}{l}\text { creating graduates who are skilled in } \\
\text { using English as their work language }\end{array}$} & FSSK & 5.9 & 8.8 & 85.3 \\
\hline & & FKAB & 21 & 27.2 & 51.9 \\
\hline & & FPI & 2.3 & 9.3 & 88.4 \\
\hline & & FST & 4.4 & 14.3 & 81.3 \\
\hline & & FEP & 7.1 & 15.7 & 77.1 \\
\hline \multirow{6}{*}{12} & \multirow{5}{*}{ creating graduates with leadership skills } & FSSK & - & 8.8 & 91.2 \\
\hline & & FKAB & 13.6 & 21 & 65.4 \\
\hline & & FPI & & 9.3 & 90.7 \\
\hline & & FST & & 3.3 & 96.7 \\
\hline & & FEP & & 7.1 & 92.9 \\
\hline & & FSSK & & & 100 \\
\hline & & FKAB & 11.1 & 19.8 & 69.1 \\
\hline 13 & creating graduates who can communicate & FPI & & 2.3 & 97.7 \\
\hline & & FST & & 2.2 & 97.8 \\
\hline & & FEP & & 5.7 & 94.3 \\
\hline & & FSSK & & 2.9 & 97.1 \\
\hline & creating graduates with leadership and & FKAB & 9.9 & 16 & 74.1 \\
\hline 14 & direction in the context of function and & FPI & & 2.3 & 97.7 \\
\hline & role of the society & FST & 1.1 & 4.4 & 94.5 \\
\hline & & FEP & & 4.3 & 95.7 \\
\hline
\end{tabular}


The table above shows that the students from both streams agree that general studies are able to fulfill human requirements. The human skills outlined in the UKM cover eight aspects which are Social Skills and Responsibility, Creative and Innovative Skills, Management and Entrepreneurial Skills, Leadership and Teamwork skills, Critical Thinking Skills, Problem-Solving and Scientific Approach, Value Skills, Attitude, Ethics and Professionalism, Information Management and dan Lifelong Learning Skills and Communication Skills. This is consistent with the work of Mohd Faizal (2005) who puts forth worker characteristics, where those deemed knowledgeable and highly skilled tend to have various skills, are versatile, creative and are able to face continuous technological changes and follow lifelong learning, along with the fact that this worker needs to be adaptable to the use of the latest technology as to avoid from any potential problems that can occur in this era of globalization.

5.5 Students' Perception on General Studies According to the Faculty of Science and Technology and Faculty of Social Science In Producing Graduates With Mastery in Human Skills

Table 7. General studies according to the faculty of science and technology and faculty of social science in producing graduates with mastery in human skills

\begin{tabular}{|c|c|c|c|c|c|}
\hline No. & Statement & Faculty & Disagree \% & Slightly disagree \% & Agree $\%$ \\
\hline \multirow{5}{*}{1} & \multirow{5}{*}{$\begin{array}{l}\text { General study courses are very important and they give } \\
\text { added value to my study program }\end{array}$} & FSSK & & 8.8 & 91.2 \\
\hline & & FKAB & 14.8 & 27.2 & 58 \\
\hline & & FPI & & 2.3 & 97.7 \\
\hline & & FST & & 8.8 & 91.2 \\
\hline & & FEP & & 10 & 90 \\
\hline \multirow{5}{*}{2} & \multirow{5}{*}{$\begin{array}{l}\text { General study courses are very important in producing } \\
\text { holistic students }\end{array}$} & FSSK & & 11.8 & 88.2 \\
\hline & & FKAB & 9.9 & 39.5 & 50.6 \\
\hline & & FPI & 0 & 11.6 & 88.4 \\
\hline & & FST & 1.1 & 17.6 & 81.3 \\
\hline & & FEP & 1.4 & 20 & 78.6 \\
\hline \multirow{5}{*}{3} & \multirow{5}{*}{$\begin{array}{l}\text { General study courses are only needed as a criterion for } \\
\text { graduating }\end{array}$} & FSSK & 20.6 & 50 & 29.4 \\
\hline & & FKAB & 14.8 & 37 & 48.1 \\
\hline & & FPI & 20.9 & 20.9 & 58.1 \\
\hline & & FST & 17.6 & 37.4 & 45.1 \\
\hline & & FEP & 11.4 & 38.6 & 50 \\
\hline \multirow{5}{*}{4} & \multirow{5}{*}{$\begin{array}{l}\text { General study courses are very important as to fulfill the } \\
\text { requirements of MQF }\end{array}$} & FSSK & & 11.8 & 88.2 \\
\hline & & FKAB & 7.4 & 33.3 & 59.3 \\
\hline & & FPI & 2.3 & 11.6 & 86 \\
\hline & & FST & 4.4 & 19.8 & 75.8 \\
\hline & & FEP & & 18.6 & 81.4 \\
\hline \multirow{5}{*}{5} & \multirow{5}{*}{ General study courses are burdensome to me } & FSSK & 50 & 38.2 & 11.8 \\
\hline & & FKAB & 38.3 & 30.9 & 30.9 \\
\hline & & FPI & 25.6 & 30.2 & 44.2 \\
\hline & & FST & 33 & 41.8 & 25.3 \\
\hline & & FEP & 38.6 & 41.4 & 20 \\
\hline \multirow{5}{*}{6} & \multirow{5}{*}{$\begin{array}{l}\text { General study courses are important as students' preparation } \\
\text { to enter the working world }\end{array}$} & FSSK & & 14.7 & 85.3 \\
\hline & & FKAB & 16 & 23.5 & 60.5 \\
\hline & & FPI & 0 & 7 & 93 \\
\hline & & FST & 4.4 & 8.8 & 86.8 \\
\hline & & FEP & 1.4 & 10 & 88.6 \\
\hline \multirow{3}{*}{7} & \multirow{3}{*}{ My value is increased after I take the general study course } & FSSK & 2.9 & 14.7 & 82.4 \\
\hline & & FKAB & 13.6 & 29.6 & 56.8 \\
\hline & & FPI & 2.3 & 9.3 & 88.4 \\
\hline
\end{tabular}




\begin{tabular}{|c|c|c|c|c|c|}
\hline No. & Statement & Faculty & Disagree $\%$ & Slightly disagree \% & Agree $\%$ \\
\hline \multirow{7}{*}{8} & \multirow{7}{*}{$\begin{array}{l}\text { My attitude is generally improved to become more positive } \\
\text { after I take the general study course }\end{array}$} & FST & 3.3 & 17.6 & 79.1 \\
\hline & & FEP & & 18.6 & 81.4 \\
\hline & & FSSK & 2.9 & 17.6 & 79.4 \\
\hline & & FKAB & 11.1 & 33.3 & 55.6 \\
\hline & & FPI & & 9.3 & 90.7 \\
\hline & & FST & 2.2 & 13.2 & 84.6 \\
\hline & & FEP & & 18.6 & 81.4 \\
\hline \multirow{5}{*}{9} & \multirow{5}{*}{$\begin{array}{l}\text { My professionalism is improved after I take a general study } \\
\text { course }\end{array}$} & FSSK & 5.9 & 17.6 & 76.5 \\
\hline & & FKAB & 11.1 & 35.8 & 53.1 \\
\hline & & FPI & & 7 & 93 \\
\hline & & FST & 1.1 & 17.6 & 81.3 \\
\hline & & FEP & & 25.7 & 74.3 \\
\hline \multirow{5}{*}{10} & \multirow{5}{*}{$\begin{array}{l}\text { My ability to communicate has become better after I take } \\
\text { General study courses }\end{array}$} & FSSK & & 11.8 & 88.2 \\
\hline & & FKAB & 8.6 & 33.3 & 58 \\
\hline & & FPI & & 11.6 & 88.4 \\
\hline & & FST & & 12.1 & 87.9 \\
\hline & & FEP & 1.4 & 10 & 88.6 \\
\hline \multirow{5}{*}{11} & \multirow{5}{*}{$\begin{array}{l}\text { My leadership skills have become better after I take General } \\
\text { study courses }\end{array}$} & FSSK & 2.9 & 26.5 & 70.6 \\
\hline & & FKAB & 8.6 & 33.3 & 58 \\
\hline & & FPI & 2.3 & 11.6 & 86 \\
\hline & & FST & 1.1 & 13.2 & 85.7 \\
\hline & & FEP & 1.4 & 17.1 & 81.4 \\
\hline \multirow{5}{*}{12} & \multirow{5}{*}{$\begin{array}{l}\text { My ability to work in a team has improved after I take } \\
\text { General study courses }\end{array}$} & FSSK & & 5.9 & 94.1 \\
\hline & & FKAB & 6.2 & 25.9 & 67.9 \\
\hline & & FPI & & 7 & 93 \\
\hline & & FST & 1.1 & 7.7 & 91.2 \\
\hline & & FEP & & 11.4 & 88.6 \\
\hline \multirow{5}{*}{13} & \multirow{5}{*}{$\begin{array}{l}\text { My ability to solve problems has become better after I take } \\
\text { General study courses }\end{array}$} & FSSK & & 17.6 & 82.4 \\
\hline & & FKAB & 13.6 & 35.8 & 50.6 \\
\hline & & FPI & 0 & 16.3 & 83.7 \\
\hline & & FST & 1.1 & 11 & 87.9 \\
\hline & & FEP & 1.4 & 18.6 & 80 \\
\hline \multirow{5}{*}{14} & \multirow{5}{*}{$\begin{array}{l}\text { My ability to manage information has improved after I take } \\
\text { General study courses }\end{array}$} & FSSK & & 20.6 & 79.4 \\
\hline & & FKAB & 8.6 & 33.3 & 58 \\
\hline & & FPI & & 14 & 86 \\
\hline & & FST & & 11 & 89 \\
\hline & & FEP & & 11.4 & 88.6 \\
\hline \multirow{5}{*}{15} & \multirow{5}{*}{$\begin{array}{l}\text { My lifelong learning skills have improved after I take } \\
\text { General study courses }\end{array}$} & FSSK & 2.9 & 17.6 & 79.4 \\
\hline & & FKAB & 21 & 24.7 & 54.3 \\
\hline & & FPI & & 11.6 & 88.4 \\
\hline & & FST & & 20.9 & 79.1 \\
\hline & & FEP & & 18.6 & 81.4 \\
\hline \multirow{5}{*}{16} & \multirow{5}{*}{$\begin{array}{l}\text { My scientific skills have improved after I take General study } \\
\text { courses }\end{array}$} & FSSK & 5.9 & 20.6 & 73.5 \\
\hline & & FKAB & 21 & 33.3 & 45.7 \\
\hline & & FPI & & 16.3 & 83.7 \\
\hline & & FST & 2.2 & 28.6 & 69.2 \\
\hline & & FEP & 1.4 & 28.6 & 70 \\
\hline
\end{tabular}




\begin{tabular}{|c|c|c|c|c|c|}
\hline No. & Statement & Faculty & Disagree $\%$ & Slightly disagree \% & Agree $\%$ \\
\hline \multirow{5}{*}{17} & \multirow{5}{*}{$\begin{array}{l}\text { My social skills have improved after I take General study } \\
\text { courses }\end{array}$} & FSSK & 2.9 & 5.9 & 91.2 \\
\hline & & FKAB & 13.6 & 25.9 & 60.5 \\
\hline & & FPI & & 2.3 & 97.7 \\
\hline & & FST & 2.2 & 7.7 & 90.1 \\
\hline & & FEP & 0 & 12.9 & 87.1 \\
\hline \multirow{5}{*}{18} & \multirow{5}{*}{$\begin{array}{l}\text { My social responsibilities improve after I take General study } \\
\text { courses }\end{array}$} & FSSK & 2.9 & 11.8 & 85.3 \\
\hline & & FKAB & 11.1 & 30.9 & 58 \\
\hline & & FPI & & 7 & 93 \\
\hline & & FST & 2.2 & 12.1 & 85.7 \\
\hline & & FEP & & 14.3 & 85.7 \\
\hline \multirow{5}{*}{19} & \multirow{5}{*}{$\begin{array}{l}\text { My entrepreneurial skills improve after I take General study } \\
\text { courses }\end{array}$} & FSSK & 14.7 & 20.6 & 64.7 \\
\hline & & FKAB & 30.9 & 37 & 32.1 \\
\hline & & FPI & 2.3 & 18.6 & 79.1 \\
\hline & & FST & 6.6 & 40.7 & 52.7 \\
\hline & & FEP & 5.7 & 21.4 & 72.9 \\
\hline
\end{tabular}

The table above shows UKM students' views on enhanced human skills through general studies. The majority of UKM students (exceeding more than 70 percent) agreed that their generic skills had improved after they took up generic skill courses such as adopting positive attitude, professionalism, communicative ability, leadership skills, and the ability to work in a team, the ability to solve problems, lifelong learning skills and social responsibilities. However, there are also some generic skills that do not really improve them, (less than 70 percent) such as scientific skills, social responsibilities and entrepreneurial skills. This is consistent with Mohd Faizal (2005) who has introduced 'knowledgeable' and 'highly skilled' as employee characteristics with a lot of skills, versatility, creativity and having the capability to face ongoing technological changes and follow lifelong learning and adapt to the latest technological use to steer clear of any adversity that can emerge in this globalized era. At the same time, UKM needs to give attention to scientific skills, social responsibilities and entrepreneurial skills that are still lacking among UKM students.

\section{Implication and Suggestion}

The data analysed demonstrate that although generally UKM students have grasped the philosophy and importance of general studies, if we look at it closely, there is a significant relationship between gender, race and faculty with the level of understanding. This means the lackadaisical attitude on general study courses is not due to the lack of understanding alone. Nonetheless, as there is still a significant relationship between the level of understanding and acceptance with several variables so the effort to improve the levels of understanding and acceptance towards education courses should be continued. The program introduced to realize this should be diversified according to suitability and preference, centralizing on gender, race and faculty. Among the actions proposed are as follows:

1) Centers that offer general study courses should ensure that information on the importance and relevance of general study courses need to be disseminated in various forms and the information should be easy to obtain. First year students in particular must be briefed clearly and sufficiently on general studies since week 1 .

2) The faculty also needs to play its role by stressing to students that general study courses actually give an added value to their fields of specification.

3) Creating a specific committee that observes general study courses offered every three year as to ensure that the courses offered are consistent with students' interests and also the industrial requirements.

4) Centers offering general study courses need to be more innovative in the teaching and delivery of courses so that students become more interested.

\section{Closing}

Although the concept of general studies has already been introduced for the past three decades and officials from Higher Learning Ministry have stressed on their importance through the introduction of human skills, but some of the academicians and students still regard the courses as burdensome, and either they need to be reduced or 
abolished. Students may be influenced by the expectations of the society that has exerted too much pressure on specification-related courses. Academicians also view that the total number of credit hours allocated for the specific courses is insufficient and this necessitates credit hours for other courses (especially general studies) to be lessened.

This study proves that the negative views are not caused by students' lack of understanding on general study philosophy. The data analysed demonstrate that the level of understanding among students is generally high. On this note, policy makers and university administrators must go to great length to overcome this problem. Other than formulating a curriculum that matches the needs of the society and the country, the effort to promote the importance of general studies should be enhanced in order to gain the interests of the students.

Investment in general study courses will benefit both the society and the nation in long term, as this course will give rise to leaders who can function effectively in the world that has always been, and is, embroiled in the turmoil of changes.

\section{References}

Ahmad, M. F. (2005). Tahap Penguasaan Kemahiran Generik Di Kalangan Pelajar Perakaunan Semester Akhir: Satu Tinjauan di Tiga Buah Politeknik dan Kolej Komuniti. Thesis, University Tun Hussein Onn Malaysia.

Association of American Colleges and Universities. (2008). College learning for the new global century: Executive summary with employers' views on learning outcomes and assessment approaches. Washington, DC: Association of American Colleges and Universities.

Harvard University. (2007). Report of the Task Force on General Education. Faculty of Arts \& Science: Harvard College

Hashim, H. R., Wahab, M. N. A., \& Ali, Z. M. (2005). Pembangunan Sahsiah Mahasiswa Bersepadu: Konsep Dan Pelaksanaannya Di Kolej Universiti Kejuruteraan. Paper work presented in Engineering Support Course National Seminar, in Aseania Hotel, Langkawi 17-18 December 2005.

Lazerson, M., Wagener, U., \& Shumanis, N. (2000). Teaching and Learning in Higher Education (1980-2000), Change, 12-19. http://dx.doi.org/10.1080/00091380009601731

Nunally, S. W. (1977). Managing Construction Equipment. Engle woods Cliffs: Prentice Hall.

Oblinger, D. G., \& Verville, A. (1998). What Business Wants from Higher Education. Phoenix, Arizona: The Oryx Press.

Shatar, M., \& Mohamad, A. (2008). The University-Industry Linkage: The Role of Student Development Services Professional. Paper work presented in the Regional Convention on Student Development, Phuket, Thailand. October 29th-31st, 2008. Organized by Universiti Utara Malaysia.

\section{Copyrights}

Copyright for this article is retained by the author(s), with first publication rights granted to the journal.

This is an open-access article distributed under the terms and conditions of the Creative Commons Attribution license (http://creativecommons.org/licenses/by/3.0/). 